\title{
Experimental nest replacement suggests that the bacterial load of nests may mediate nestling physiological condition in cavity nesting Great Tits (Parus major)
}

\author{
Agnieszka Zabłotni ${ }^{1} \cdot$ Adam Kaliński $^{2} \cdot$ Mirosława Bańbura $^{3} \cdot$ Michał Glądalski $^{2} \cdot$ Marcin Markowski $^{2}$. \\ Joanna Skwarska · Jarosław Wawrzyniak ${ }^{2}$. Jerzy Bańbura²
}

Received: 8 July 2019 / Revised: 10 January 2020 / Accepted: 25 February 2020 / Published online: 14 March 2020

(c) The Author(s) 2020

\begin{abstract}
Nests of secondary-cavity breeding birds are structures constructed to lay and incubate eggs and raise nestlings to fledging. These nests are characterized by relatively stable conditions, which makes them a suitable habitat for various microorganisms. It has been suggested that bacteria inhabiting nests and nestling skin may affect nestlings both positively and negatively. In this study, nests of Great Tits Parus major were replaced with artificial nests on the fifth day of the nestling phase in two different study sites to create two categories of nests: (i) natural and (ii) artificial with a reduced bacterial load. Four days later, bacterial samples were collected from the nestling skin and from the edge of the nest to assess skin and nest bacterial loads, expressed as colony forming units (CFUs). It was predicted that (i) the previous season occupancy of nest boxes would influence bacterial loads, (ii) the experimental treatment would reduce nest and skin bacterial loads, and (iii) that nest and skin bacterial loads would affect the condition of the nestlings, assessed as the hemoglobin concentration in blood when nestlings were 14 days old. Occupancy in the previous season did not affect the bacterial load. The skin bacterial load was significantly lower in artificial nests, although the nest bacterial load did not differ between natural and artificial nests. Nestlings from artificial nests had higher hemoglobin, and hemoglobin concentration was negatively associated with the nest but not the skin bacterial load. Our results suggest that the bacterial load in nests may negatively affect the physiological condition of avian hosts.
\end{abstract}

Keywords Nest bacterial load $\cdot$ Skin bacterial load $\cdot$ Nest replacement $\cdot$ Great tit $\cdot$ Hemoglobin $\cdot$ Nestling condition

\section{Zusammenfassung}

Nestaustauschexperimente liefern Hinweise auf einen Einfluss der Bakterienbelastung der Nester auf die physiologische Kondition der Nestlinge höhlenbrütender Kohlmeisen (Parus major)

Die Nester sekundärer Höhlenbrüter sind Gebilde, welche für Eiablage, Bebrütung und die Aufzucht der Nestlinge bis zum Flüggewerden errichtet werden. Diese Nester zeichnen sich durch relative stabile Bedingungen aus, was sie zu einem geeigneten Lebensraum für diverse Mikroorganismen macht. Es wird vermutet, dass die Bakterien, welche in den Nestern und auf der Haut der Nestlinge leben, die Nestlinge sowohl positiv als auch negativ beeinflussen können. In dieser Studie ersetzten wir in zwei verschiedenen Untersuchungsgebieten Nester von Kohlmeisen Parus major am fünften Tag der Nestlingsphase durch Kunstnester und schufen dadurch zwei Nestkategorien: (i) Naturnester und (ii) Kunstnester mit verringerter Bakterienbelastung. Vier Tage später nahmen wir Bakterienproben von der Haut der Nestlinge sowie vom

Communicated by S. Bouwhuis.

Adam Kaliński

adam.kalinski@biol.uni.lodz.pl

1 Laboratory of General Microbiology, Department of Biology of Bacteria, Faculty of Biology and Environmental Protection, University of Łódź, Banacha 12/16, 90-237 Lodz, Poland
2 Department of Experimental Zoology and Evolutionary Biology, Faculty of Biology and Environmental Protection, University of Łódź, Banacha 12/16, 90-237 Lodz, Poland

3 Museum of Natural History, Faculty of Biology and Environmental Protection, University of Łódź, Kilińskiego 101, 90-011 Lodz, Poland 
Nestrand, um die Bakterienbelastung der Haut und der Nester zu ermitteln, ausgedrückt als koloniebildende Einheiten (engl.: colony forming units; CFUs). Wir sagten voraus, dass (i) die Belegung der Nistkästen in der vorangegangenen Saison die Bakterienbelastung beeinflusst, (ii) die Bakterienbelastung von Haut und Nestern durch den experimentellen Eingriff geringer wird und (iii) dass die Bakterienbelastung von Nestern und Haut die Kondition der Nestlinge, ausgedrückt durch die Hämoglobinkonzentration im Blut der Nestlinge im Alter von 14 Tagen, beeinflusst. Eine Nistkastenbelegung in der vorherigen Saison hatte keinen Einfluss auf die Bakterienbelastung. Die Bakterienbelastung der Haut war in den Kunstnestern signifikant niedriger, obgleich sich die Bakterienbelastung der Nester zwischen Natur- und Kunstnestern nicht unterschied. Nestlinge aus Kunstnestern hatten einen höheren Hämoglobinwert, und die Hämoglobinkonzentration stand in negativer Beziehung zur Bakterienbelastung des Nests, allerdings nicht zu derjenigen der Haut. Unsere Ergebnisse legen nahe, dass die Bakterienbelastung der Nester einen negativen Einfluss auf die physiologische Kondition der Wirtsvögel haben kann.

\section{Introduction}

Avian nests are structures used for incubating eggs and raising young (Collias and Collias 1984; Hansell 2000). Nests of secondary-cavity breeding birds are complex structures and their main function is to establish a proper environment for eggs and nestlings. Nests provide thermal insulation, help to maintain a proper position of eggs during incubation and protect offspring from predators (Alabrudzińska et al. 2003; Alvarez et al. 2013). In the case of European tits (Paridae), the thick moss-made base of the nest may serve as a store of feces, remnants of food, peeled-off fragments of epidermis or even unhatched eggs and dead nestlings (Gosler 1993; Bańbura et al. 2001). Such nests constitute a unique environment suitable for macroorganisms and ectoparasites (Allander 1998; Heeb et al. 2000; Słomczyński et al. 2006), and allow colonization by a variety of microbial species (Benskin et al. 2009; Goodenough and Stalwood 2010; Berger et al. 2003; Devaynes et al. 2018). Bacteria in the nest originate from various sources, including the nesting material, adult birds, their skin, feathers and excreted feces (Burtt and Ichida 1999; Mills et al. 1999).

Some of the bacterial species of the rich nest-dwelling assembly are commensals inhabiting the nest structure and exploiting nest components that are rich in organic matter. The presence of some of these bacteria may be beneficial or even crucial to the well-being of their avian hosts. Several studies have shown that microbes positively influence avian host fitness in the wild. For example, bacteria living in the uropygial gland of Hoopoes Upupa epops produce antimicrobial peptides active against a broad spectrum of pathogenic bacteria, which suggests a tight symbiosis between bacteria and their avian host (Soler et al. 2008). Similarly, Enterococcus faecium has been found to increase fitness of nestling Pied Flycatchers Ficedula hypoleuca because it produces enterocins, which have inhibitory effects on pathogenic Enterococcus faecalis strains (Moreno et al. 2003). Furthermore, Blue Tits Cyanistes caeruleus show a negative relationship between egg mortality and bacterial counts (Devaynes et al. 2018). Several other studies have also shown beneficial effects of enteric microbiota, including the reduction of potentially pathogenic strains; however, they concern mainly captive birds, such as poultry (Carina-Audisio et al. 2000; La Ragione et al. 2001), with still very little data on wild animals.

On the other hand, some bacterial strains may have harmful effects on their avian hosts. Some microorganisms, particularly fungi from the genus Cladosporium, have allergenic properties (Hubalek 1978). Some are pathogens that can cross the eggshell and infect the embryo, thus reducing egg viability, and, in consequence, lead to hatching failure (Pinowski et al. 1994; Cook et al. 2005; Lee et al. 2014). Moreover, skin microbiota disturbance may be linked with various diseases (Hubalek 2004; Benskin et al. 2009). For example, Salmonella, the intestinal species that can cause salmonellosis, was found in House Wren Troglodytes aedon nests (Singleton and Harper 1998) and may also colonize the nestling skin and subsequently cause disease. Bacterial species inhabiting bird plumage should not be neglected either. They are capable of degrading feather keratin, which may affect flight ability and the thermoregulatory properties of the plumage (Burtt and Ichida 1999; Saag et al. 2011).

For these reasons, keeping both skin and feathers in good condition is of importance for all avian species. For this purpose, most of them possess the uropygial gland, which produces secretions used to coat the plumage (Piersma et al. 1999). A study on Great Tits Parus major demonstrated that the quantity and chemical composition of uropygial secretions changes depending on their exposure to bacteria (Jacob et al. 2014). Similar patterns were found in captive Feral Pigeons Columba livia f. urbana (Leclaire et al. 2014). Studies showing a direct impact of the bacterial load on the condition of wild birds, however, are scarce. As an exception, Gunderson et al. (2009) showed that the body condition of Eastern Bluebird Sialia sialis adult females was negatively associated with plumage bacteria intensity. Moreover, Gonzalez-Braojos et al. (2012) showed that the bacterial load of nests was negatively associated with feather growth in Pied Flycatchers and a study on Magellanic penguin Spheniscus magellanicus chicks suggested that particular bacilli may cause decreased growth rates (Potti et al. 2002). Finally, Berger et al. (2003) suggested that in Starling Sturnus vulgaris nests, a higher bacterial load in 
the late part of the breeding season might be responsible for the lower condition of second brood nestlings. These findings imply that the potential negative impact of microbial communities inhabiting the skin and feathers of several avian species may be profound.

Given the complexity of microorganism-hosts interactions in avian nests, we may expect that microorganisms exert selection pressure on nestling condition. The hemoglobin concentration in blood is a good candidate for indexing physiological condition (see Minias 2015 for a review) since it is responsible for oxygen transport, a function that develops throughout the nestling stage (Kostelecka-Myrcha and Jaroszewicz 1993). Erythrocytes containing hemoglobin are relatively short-lived cells, which makes them costly to produce and maintain at appropriate levels (Whittow 2000). In our long-term studies on Blue and Great Tits, we have shown that the concentration of hemoglobin is positively related to the physiological condition of nestlings, and is strongly correlated with the quantity and quality of food delivered by their parents (Kaliński et al. 2016, 2017). Moreover, the iron contained in hemoglobin is an essential microelement for the growth of most bacteria, which means that competition for iron is one of the major factors driving the battle between hosts and colonizing bacteria (Bullen 1981; Pishchany et al. 2010). Within the context of our study, we, therefore, consider this mechanism as the way in which the microbial load could affect the hemoglobin concentration in growing nestlings.

We conducted an experimental study on Great Tits during the nestling period, in which we replaced some nests by artificial nests, while leaving others unmanipulated. Using clean, fresh nest material, we aimed to create artificial nests with a substantially reduced bacterial load and, consequently, a reduced number of microorganisms on the nestling skin. We then estimated the nest and skin bacterial loads to test the following predictions: (i) artificial nests have lower bacterial loads than natural nests, (ii) nestlings from artificial nests carry lower bacterial loads on their skin than nestlings from natural nests, and (iii) the physiological condition of nestlings with a lower bacterial load differs from that of nestlings from unmanipulated broods. In addition, we tested whether the presence or absence of tit nests in the studied nest boxes in the preceding season affected bacterial communities in the current breeding attempt even though all nest boxes were cleaned up after the breeding season, in autumn.

\section{Materials and methods}

\section{Study sites}

This study was carried out in 2018 as part of a long-term research program on the breeding biology of Blue Tits and
Great Tits in Łódź, central Poland in two different areas: an urban parkland and a deciduous forest (Kaliński et al. 2017; Bańbura et al. 2011). These two sites are located $10 \mathrm{~km}$ apart and differ structurally and floristically. The urban parkland study site $\left(51^{\circ} 45^{\prime} \mathrm{N} ; 19^{\circ} 24^{\prime}\right.$ E) consists of Łódź Botanical and Zoological Garden and covers a total area of ca. 80 ha. It has a fragmented tree and bush cover, formed mainly artificially with very few remnants of natural stands (Glądalski et al. 2016). The forest study site $\left(51^{\circ} 50^{\prime} \mathrm{N} ; 19^{\circ}\right.$ $29^{\prime} \mathrm{E}$ ) is an area of ca. 145 ha located in the interior of a rich, mature mixed deciduous forest called the Lagiewniki Forest (1250 ha in total). Oaks (Quercus robur and Q. petrea) are the predominant tree species in the forest. Both study sites were supplied with standard wooden nest boxes (200 in the parkland area and 300 in the forest area). During the breeding season, the study sites were inspected daily to record characteristics of each clutch, including clutch size and nestling number. After each breeding season each nest box was cleaned with a wire brush, such that no visible nest remnants were left.

\section{Experimental procedure}

In the 2018 breeding season, 20 out of 42 clutches of Great Tits were randomly assigned to the experimental treatment (10 in the parkland study site and 10 in the forest study site) and 22 to the control treatment (11 in the urban parkland and 11 in the forest). Of these clutches, 24 were produced in nest boxes that contained successful Great or Blue tit broods in 2017, while 18 were produced in nest boxes that were unoccupied in the previous year. In the experimental group, the original nests were replaced with artificial nests 5 days after hatching. The structural base of the artificial nests was made of moss and pure cotton wool was used as a nest lining. Moss was collected before the experimental procedure and dried for $48 \mathrm{~h}$ at $25^{\circ} \mathrm{C}$. Any arthropods found in the moss were removed at this stage. This procedure allowed creating a binary predictor: microorganism-reduced nests vs. natural nests (control). The mean number of nestlings did not differ between the experimental and control nests in the urban parkland $(8.80 \pm 1.69 \mathrm{SE}$ vs. $7.27 \pm 1.85$; Student's $t$ test for independent samples, $t=-1.97, d f=19, p=0.063$ ) or in the forest $(9.30 \pm 1.33$ SE vs. $10.38 \pm 1.47$; Student's $t$ test for independent samples, $t=1.43, d f=19, p=0.168$ ).

\section{Bacterial sampling}

On day 9 of the nestling phase, bacteria were sampled by swabbing (using a procedure standardized as to the time and area) the naked skin of 2 blindly drawn nestlings per nest, as well as the surface of the corresponding nest. Using disinfected latex gloves, nestlings were removed from the nest boxes and their unfeathered ventral side (belly) was swabbed 
for $30 \mathrm{~s}$ with a sterile cotton swab previously moistened with sterile phosphate-buffered saline (PBS, pH 7.2; Adlab, Poland). Subsequently, the limited surface of the upper edge of the nest material was swabbed in the same manner, using an ethanol-treated, rigid plastic sheet where a $2.25 \mathrm{~cm}^{2}$ square was cut out. One sample per nest was taken. Bacteria collected on the swabs were immediately placed into transport media Amies (Hagmed, Poland) and transported in a portable cooler (equipped with cooling cartridges) to the laboratory (maximum time 3-4 h).

\section{Lab procedures}

Once in the laboratory, the swabs were shaken vigorously in a manner standardized to a time (about $30 \mathrm{~s}$ per swab) to allow the passage of bacteria to the solution, and serial dilutions of the suspension were made $\left(10^{-1}\right.$ to $\left.10^{-4}\right)$ in sterile physiological saline $(0.85 \% \mathrm{NaCl}, \mathrm{pH} 7.2)$. Next, $100 \mu \mathrm{l}$ of the original suspension and each dilution was plated on Tryptic Soy Agar (TSA; GrasoBiotech, Poland). TSA is a nutrient medium used for the cultivation of a wide range of heterotrophic, aerobic, culturable bacteria. The plates were incubated for $48 \mathrm{~h}$ at $37 \pm 1{ }^{\circ} \mathrm{C}$ then for 48 additional $\mathrm{h}$ at $25 \pm 1^{\circ} \mathrm{C}$ and the colony forming units (CFU) were counted.

The results were expressed as $\mathrm{CFU} / \mathrm{ml}$.

\section{Physiological measurements}

When the nestlings were 13-14 days old, they were banded with individually numbered metal rings and measured. Because the nestlings could not be individually recognized during the bacterial sampling and because this study is a part of a long term research project on the physiology of cavity nesting birds in central Poland, we used a general protocol (i.e. Kaliński et al. 2015). Therefore, a random subsample of 3 nestlings per brood was designated for blood sampling. Samples of $5 \mu \mathrm{l}$ of blood were taken from the ulnar vein of nestlings to HemoCue cuvettes and analyzed in the field using a portable HemoCue $\mathrm{Hb} 201+$ photometer to measure the hemoglobin concentration $(\mathrm{g} / \mathrm{l})$ (Kaliński et al. 2015). All field procedures were carried out between 9.00 and 14.00. In total, 113 great tit nestlings from both nest categories were blood sampled (57 from artificial nests, 56 from control ones).

\section{Statistical analyses}

The nest bacterial load and skin bacterial load variables were normalized through $\ln$ transformation prior to analyses. Because the values of the skin bacterial load and hemoglobin concentration in the blood of nestlings from the same brood are not independent, the individual nestling values were treated as unit records (they were not pooled) and were nested within brood ID. Then, the values were analyzed using linear mixed models, with brood ID being included as a random effect to control for clustering; degrees of freedom were approximated by the Satterthwaite method (Heck et al. 2010). First, it was tested whether the study area, occupancy of the nest box in the previous year and experimental treatment affected the nest bacterial load and the skin bacterial load. Next, it was tested whether the hemoglobin concentration in the nestling blood was affected by the nest bacterial load and the skin bacterial load. Experimental treatment, nest box occupancy in the previous year and study site were included as fixed factors in this model, both as main effects and in interaction with each other. This analysis was conducted with the model with the nest bacterial load and skin bacterial load as independent variables (Crawley 2002). The full models were simplified by removing non-significant interactions beginning from the least significant ones to obtain final models (Crawley 2002). Linear mixed modeling was performed using IBM SPSS Statistics 22 software (Heck et al. 2010; IBM SPSS Statistics 22 2013). Within-brood repeatabilities $(R)$ for skin bacterial loads and hemoglobin concentration were calculated after Lessells and Boag (1987); while standard errors were estimated following Becker (1984).

\section{Results}

Mean, minimum and maximum of $\ln$-transformed values of the nest bacterial loads and skin bacterial loads in the control and the experimental nests in both study sites are given in Table 1.

The mean nest bacterial load did not differ significantly between the study areas or between the control and artificial nests, nor varied with occupancy in the previous breeding season (Table 2).

The mean skin bacterial load also did not differ significantly between the study areas and did not vary with occupancy in the previous breeding season, but it was significantly lower in experimental nests compared to control nests (Table 2, Fig. 1). The repeatability of skin bacterial load within broods was very high: $R=0.92 ; \mathrm{SE}=0.039$ (Fig. 2a).

Similarly, nestling hemoglobin concentration did not differ significantly between the study areas and did not vary with occupancy in the previous breeding season, but it was significantly higher in nestlings from artificial than control nests $(132.16 \pm 3.01$ vs. $116.91 \pm 2.49$ respectively; Table 3$)$. The repeatability of hemoglobin concentration within broods was high: $R=0.74 ; \mathrm{SE}=0.062$ (Fig. 2b). Furthermore, we found that the treatments differed with respect to a relationship between the nestling hemoglobin concentration and the nest bacterial load; it was significantly negative in the case of the control group (estimated effect $-4.630 \pm 1.175 \mathrm{SE}$ ) and non-significant in 
Table 1 The mean, minimum and maximum values of the nest bacterial load (upper) and skin bacterial load (lower) in the parkland and forest study areas in both nest categories (experimental and control) in $\mathrm{CFU} / \mathrm{ml}$

\begin{tabular}{llllllll}
\hline & \multicolumn{2}{l}{ Parkland } & & & & Forest & \\
\cline { 2 - 3 } & Mean & Min & Max & & Mean & Min & Max \\
\hline Experimental & $6.27( \pm 2.20)$ & 2.30 & 8.90 & & $6.52( \pm 2.90)$ & 3.69 & 14.02 \\
Control & $6.65( \pm 2.26)$ & 2.30 & 9.68 & & $7.96( \pm 3.91)$ & 3.69 & 15.01 \\
Experimental & $5.08( \pm 1.50)$ & 2.30 & 7.82 & & $5.03( \pm 2.90)$ & 2.30 & 8.70 \\
Control & $6.64( \pm 2.59)$ & 2.30 & 11.29 & & $7.03( \pm 3.39)$ & 3.40 & 15.80 \\
\hline
\end{tabular}

Values are $\ln$-transformed. SD values are given in parentheses
Table 2 Summary of the linear mixed models of the nest bacterial load (upper) and the skin bacterial load (lower)

\begin{tabular}{lrrr}
\hline Factor & $d f$ & \multicolumn{2}{l}{$l$} \\
\hline Nest bacterial load & $1 ; 38.00$ & 237.42 & $<\mathbf{0 . 0 0 1}$ \\
Intercept & $1 ; 38.00$ & 1.334 & 0.255 \\
$\quad$ Study area & $1 ; 38.00$ & 0.579 & 0.451 \\
Previous season occupancy & $1 ; 38.00$ & 1.184 & 0.283 \\
$\quad$ Experiment & $1 ; 34.47$ & 230.102 & $<\mathbf{0 . 0 0 1}$ \\
Skin bacterial load & & & \\
Intercept & $1 ; 38.24$ & 1.108 & 0.299 \\
$\quad$ Study area & $1 ; 38.25$ & 0.950 & 0.336 \\
Previous season occupancy & $1 ; 38.03$ & 4.933 & $\mathbf{0 . 0 3 2}$ \\
Experiment & & & \\
\hline
\end{tabular}

Effects of the study area, nest box occupancy in the previous season and experimental treatment are given. Significant values are in bold. Variance estimates in the second model for brood ID are as follows: $F=22.23 ; \mathrm{MS}=13.674 ;$ Error $=0.615 ; p<0.001$

the nest-treatment group (estimated effect $0.579 \pm 1.251$ SE), as shown by the bacterial load-treatment interaction (Table 3, Fig. 3). No such effect was found for the skin bacterial load (Table 3 ).

\section{Discussion}

We found that our experimental treatment of nest replacement did not affect nest bacterial load. Conversely, our experimental procedure did affected the nestlings' skin bacterial load, which was significantly lower in the artificial nests. In addition, both our experimental treatment and the nest bacterial load correlated with the nestling hemoglobin concentration. These results are partly consistent with our predictions, as discussed below.

We expected that, as a result of replacing natural nests with artificial ones, the total amount of bacteria inhabiting the nests would be substantially reduced, which was not the case. The lack of a difference between the artificial and natural nests suggests two potential and non-mutually exclusive explanations. First, the materials used for creating the artificial nests may have not been sterile. Second, bacterial sampling was conducted 4 days after the nest replacement procedure, which may have provided sufficient time for various bacterial strains to grow and proliferate.

Despite the fact that the nest bacterial load was not affected by our experimental treatment, nestlings reared in artificial nests had a lower bacterial load than nestlings from
Fig. 1 Mean ( \pm standard errors) nestling skin bacterial load in experimentally treated and control nests in two study areas

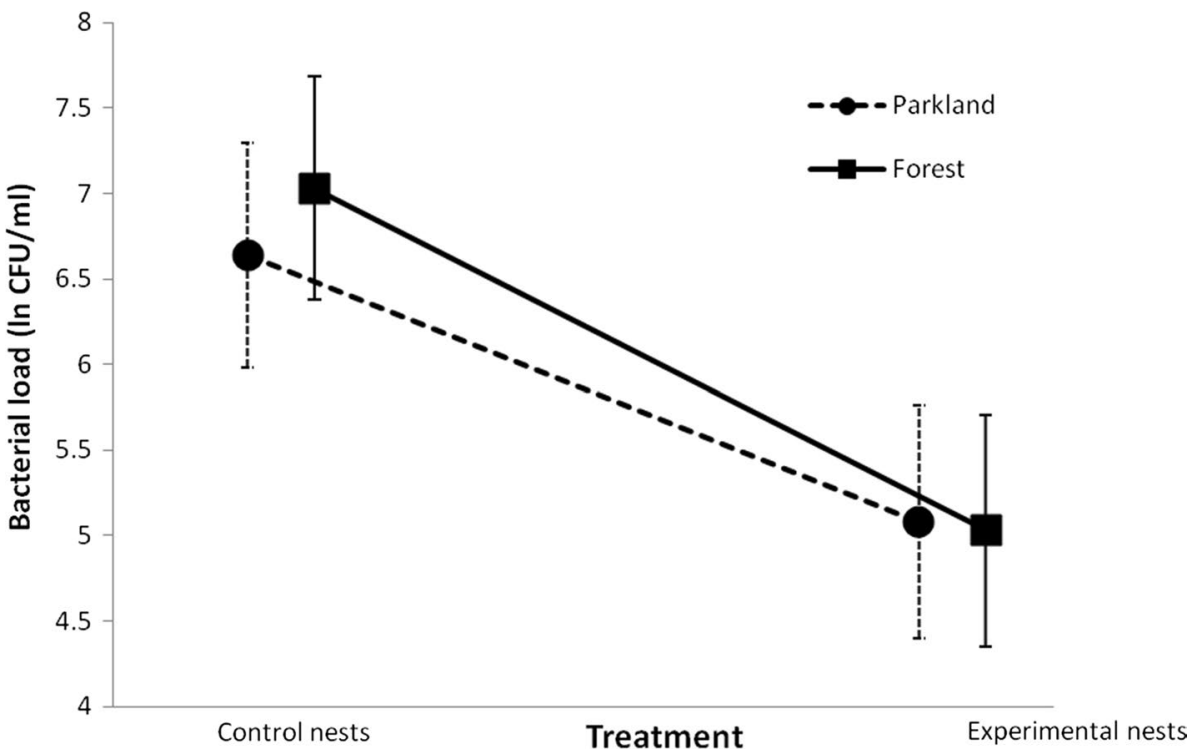


Fig. 2 Two randomly chosen chicks from each nests plotted against each other in $\mathrm{x}$ and $\mathrm{y}$ axes for ln skin bacterial load (a) and hemoglobin concentration (b)
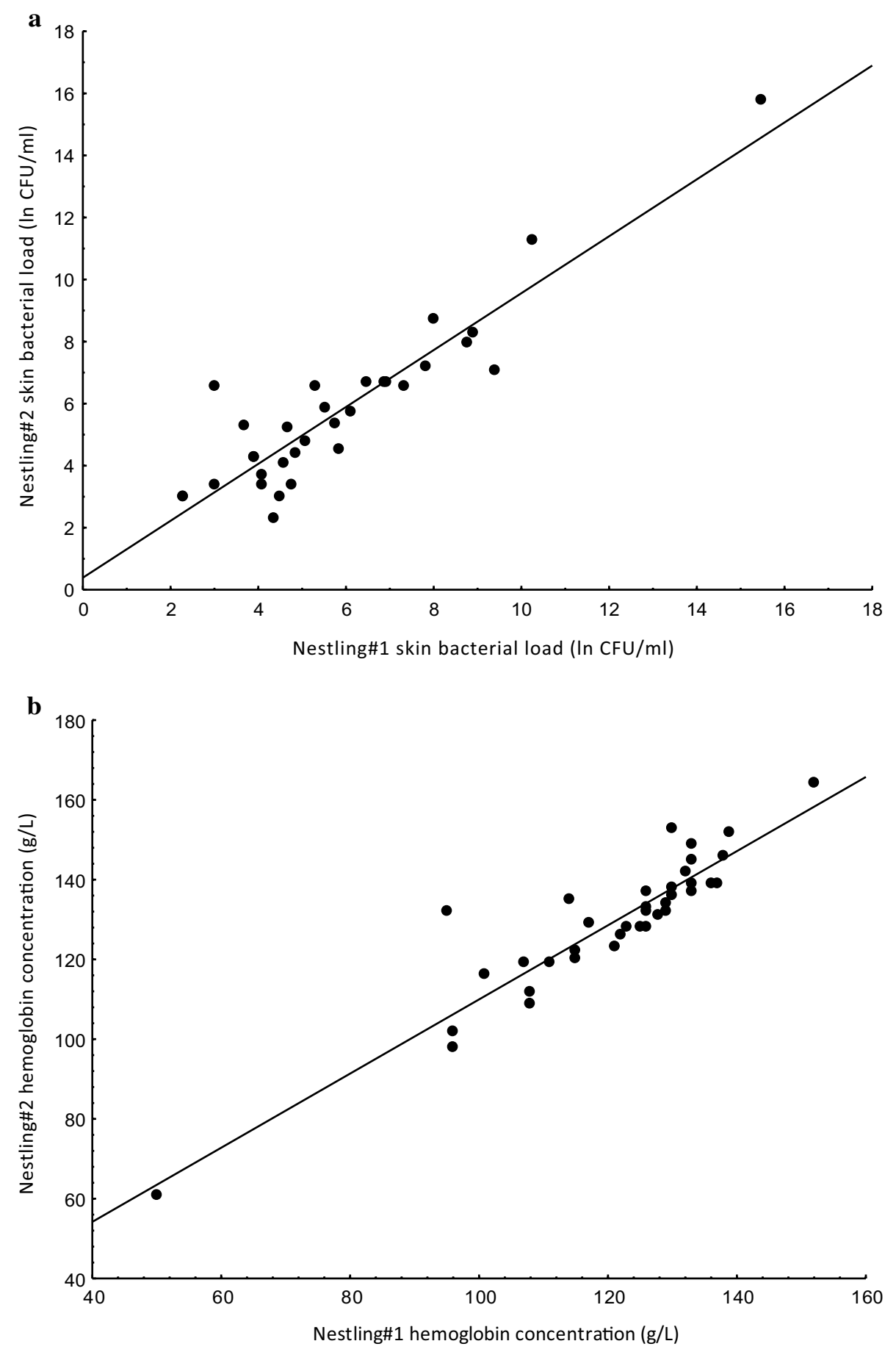

the unmanipulated nests. This suggests that the development and maintenance of bacterial communities on nestling skin may be linked to the environment in which nestlings are reared, independent of the bacterial load of the nest itself. It is also possible that part of the microorganisms had moved from chicks to the nest content which then became a new habitat for them. Previous studies on the consequences of nest replacement for arthropod parasite load indicated that nest replacement might substantially decrease parasite infestation and thus positively influence nestling fitness (see, e.g., Słomczyński et al. 2006). To the best of our knowledge, our report is the first to show an impact of nest replacement on nestling skin bacterial loads. It thereby corroborates the results of a study by Gonzalez-Braojos et al. (2012), which showed that Pied Flycatcher nestlings raised in reused nests had a significantly higher skin bacterial load than nestlings from nests built in empty nest boxes. Bearing in mind that factors responsible for the variation in microbial 
Table 3 Summary of the linear mixed models of the hemoglobin concentration in the blood of great tit nestlings

\begin{tabular}{llrr}
\hline Factor & \multicolumn{1}{l}{ df } & \multicolumn{1}{r}{$p$} \\
\hline Intercept & $1 ; 22.08$ & 864.45 & $<\mathbf{0 . 0 0 1}$ \\
Study area & $1 ; 16.80$ & 0.54 & 0.473 \\
Previous season occupancy & $1 ; 16.92$ & 0.69 & 0.417 \\
Experiment & $1 ; 21.81$ & 5.77 & $\mathbf{0 . 0 2 5}$ \\
Nest bacterial load & $1 ; 19.11$ & 7.50 & $\mathbf{0 . 0 1 3}$ \\
Skin bacterial load & $1 ; 26.73$ & 0.07 & 0.799 \\
Experiment * nest bacterial load & $1 ; 19.47$ & 12.34 & $\mathbf{0 . 0 0 2}$ \\
\hline
\end{tabular}

Effects of the study area, occupancy in the previous season, experimental treatment and $\ln$ nest bacterial load and ln skin bacterial load were analyzed. Significant values are in bold. Variance estimates in the second model for brood ID are as follows: $F=9.60$; $\mathrm{MS}=904.0$; Error $=94.0 ; p<0.001$

assemblages in cavity nesting birds are relatively weakly explored and may act differently in different species (Goodenough and Stalwood 2010, 2012), further studies concerning this issue are needed.

We consider the negative relationship between the nest bacterial load and the nestling hemoglobin concentration the most interesting result obtained in this study, as it indicates a potential impact of the bacterial load on nestling condition and fitness. The physiological condition of nestling Great Tits depends on a variety of factors including environmental stressors of different origin (O'Brien et al. 2001; Kilgas et al. 2006) and it, therefore, seems likely that hemoglobin concentration is indicative of potential disturbance, such as microbial infection. Although the exact mechanism underlying this process is largely unknown, the most probable explanation may be competition for iron between bacteria and their hosts. Vertebrates universally have body fluids that contain very little ionic iron and most of the iron is associated with proteins such as hemoglobin (Bullen 1981). Since microorganisms infecting their hosts need iron for successful proliferation, they steal it from their host, causing anemia reflecting iron shortage in the body (Hill et al. 1977). We suppose that high nest bacterial loads may contaminate the digestive tract of nestlings and cause relatively moderate infections or inflammations. Therefore, opportunistic bacteria may act as a factor reducing the hemoglobin concentration in developing nestlings. Contrary to that, the increase in the skin bacterial load did not have such an effect, which suggests that skin microorganisms constitute the nestling microbiome and are mostly beneficial. However, because we are not aware of any studies linking nest bacterial loads with hemoglobin content in nestling blood, it is necessary to focus on the studies concerning the impact of microorganisms on particular components of avian hosts fitness. In one of the first studies investigating the influence of various types of bacteria on fledgling survival, some bacteria were positively correlated with a greater degree of wing asymmetry in Tree Swallow nestlings (Mills et al. 1999). Such a result suggests that microorganisms may affect survival through the impairment of flight ability. Similar results were presented by Gonzalez-Braojos et al. (2012), who showed
Fig. 3 Correlation between nest bacterial load and nestling hemoglobin concentration for both control nests (solid circles, solid line) and experimental nests (open circles, dashed line)

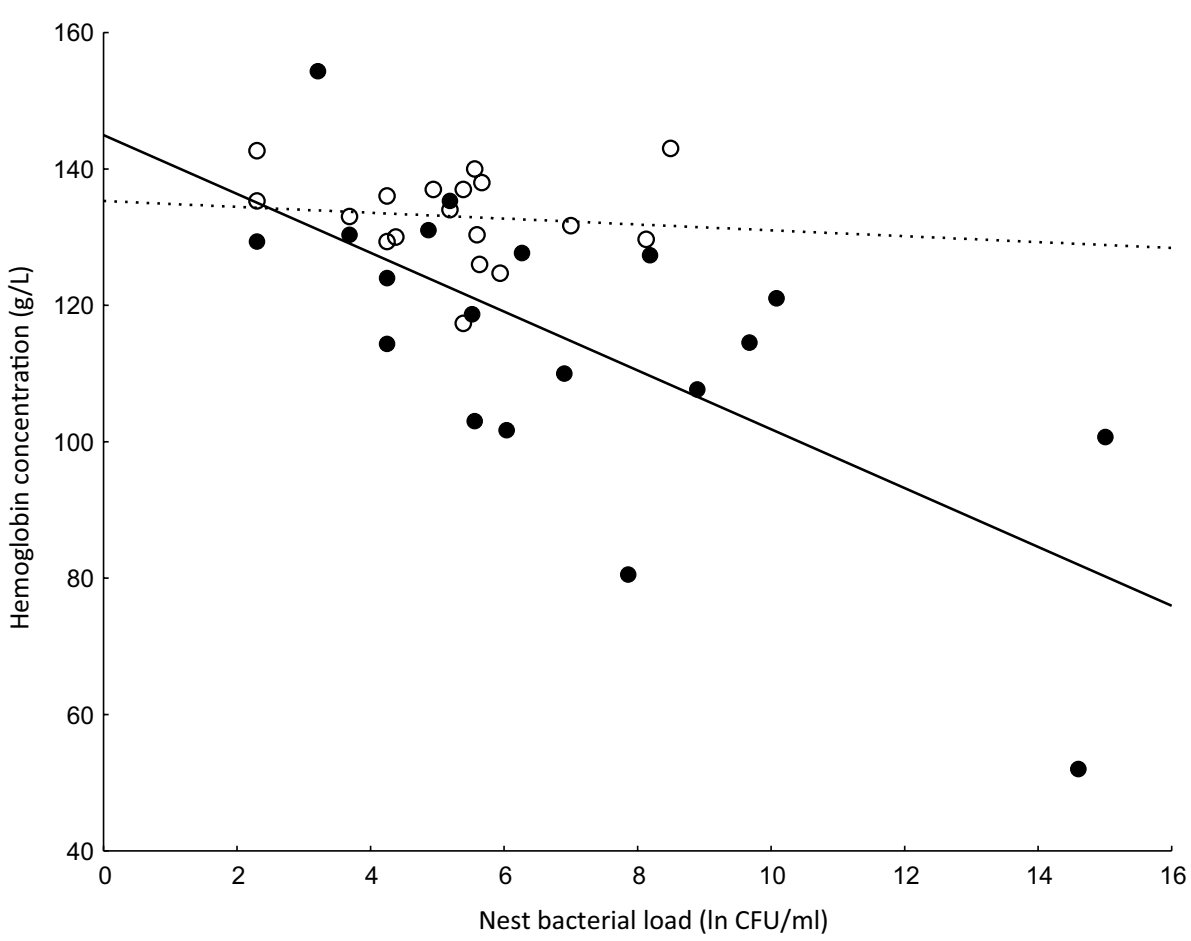


that the bacterial load in reused nests negatively influenced the feather growth of Pied Flycatcher nestlings. However, in a follow-up paper, the same team showed that skin bacteria may favor wing feather growth through competition with harmful bacteria and the authors speculated that a lack of association between skin bacterial load and body mass or skeletal growth indicates that skin bacteria do not remove resources crucial for growth (Gonzalez-Braojos et al. 2015). Beneficial effects on nestling fitness components resulting from competition between pathogenic and non-pathogenic microbial strains have been proposed in a few studies (Soler et al. 2008, 2010). Nevertheless, it should be noted that in some cases, neither beneficial nor harmful effects of microorganisms on hosts have been detected. Berger et al. (2003), for example, reported that Starlings show no relationship between nest bacterial load and body mass, nestling mortality, hatching or fledging success. As such, it seems very likely that bacterial assemblages may interact with their avian hosts in various ways. A study by Goodenough and Stalwood (2012) is a good illustration of this issue.

It should be also stressed that the better condition of nestlings in terms of hemoglobin concentration in artificial nests may be at least in part attributed to a decreased infestation of arthropod ectoparasites. In another experiment with nest replacement in both the parkland and the forest site, an analogous increase in the hemoglobin concentration in replaced nests was ascertained (Glądalski et al. 2018). It is not clear to what extent the reduction in the bacterial load alone was responsible for this result, since we have no reliable data on the prevalence of blood sucking arthropods in the nest boxes in the study season. However, earlier research conducted in our study system showed that the parasite infestation level in the nest boxes was relatively low (Słomczyński 2006).

We predicted that the occupancy of the nest box in the preceding year might influence the nest bacterial load in the current year for two reasons. First, although all nest boxes were cleaned in autumn with a wire brush, which should eliminate substantial quantities of bacteria, there is some debris left in less accessible corners of the nest box, which could be a source of bacteria colonizing the nest in the next spring. The second factor is related to winter roosting behavior in tits. It is well known that both Great and Blue Tits spend the night inside cavities, including nest boxes (Mainwaring 2011, own obs.). Great Tits roost in the nest boxes alone and use between one and four boxes, switching among them on a regular basis (Vel'ky 2006). A proportion of roosting males choose the nest box which they roost in as a breeding place in the following spring. Therefore, because the nest boxes are used throughout the year, the transmission of microorganisms between avian hosts and a nest box interior could be a widespread phenomenon. Our prediction was in tune with the results presented in a study conducted by Gonzalez-Braojos et al. (2012). The authors compared bacterial loads in reused and new nests of Pied Flycatcher and reported no significant differences between the two categories. In our study, however, such relationship was found.

We explored whether study area was a factor affecting the bacterial load of Great Tit nests and skins, but found this not to be the case. There are very few studies concerning the impact of habitat variation on bacterial communities in avian nests. In one of the exceptions, Saag and co-authors found that the number of bacterial phylotypes per Great Tit individual was higher in a coniferous habitat; while, bacterial densities were higher in a deciduous habitat (Saag et al. 2011). Moreover, they found that free-living bacterial density was positively correlated with female mass and suggested that the relatively high bacterial load associated with the deciduous habitat might contribute to habitat mediated differences in the adult condition (Saag et al. 2011). Similarly, a study by Burtt and Ichida (1999) across 83 avian species showed substantial variation in plumage bacteria to be mainly habitat dependent. It should be noted here that although we did not find any differences in bacterial load between our two study sites, it cannot be ruled out that the species composition of their microorganisms may differ.

Overall, our study demonstrated a potential negative influence of microorganisms living in avian nests on the hematological index in wild birds and that the determination of the skin bacterial load may not be sufficient to assess the physiological condition of the nestlings, which depends more on the microorganisms that inhabit the nest. However, the prevalence and species composition of bacteria in nests of secondary-cavity nesters may vary depending on a multitude of ecological factors. Therefore, further, more detailed studies, including ones identifying bacterial species, using long-term data sets and bacterial sampling in different stages of nestling development are needed.

Acknowledgements We thank A. Jaksa and E. Wróblewska for their consent to conducting our research in the areas under their administration. We are also greatly obliged to D. Mańkowska, M. Janiszewska and J. Białek for their support. We thank J. Cwynar for linguistic corrections and an anonymous reviewer for comments that improved the manuscript.

\section{Compliance with ethical standards}

Conflict of interest The authors declare that they have no conflict of interest.

Ethical statement All procedures were approved by the Local Ethical Committee in Łódź (Lokalna Komisja Etyczna do Spraw Doświadczeń na Zwierzętach w Łodzi, Uniwersytet Medyczny w Łodzi-Zakład Farmakodynamiki, ul. Muszyńskiego 1, 90-151 Łódź). All the methods were carried out under Polish law. 
Open Access This article is licensed under a Creative Commons Attribution 4.0 International License, which permits use, sharing, adaptation, distribution and reproduction in any medium or format, as long as you give appropriate credit to the original author(s) and the source, provide a link to the Creative Commons licence, and indicate if changes were made. The images or other third party material in this article are included in the article's Creative Commons licence, unless indicated otherwise in a credit line to the material. If material is not included in the article's Creative Commons licence and your intended use is not permitted by statutory regulation or exceeds the permitted use, you will need to obtain permission directly from the copyright holder. To view a copy of this licence, visit http://creativecommons.org/licenses/by/4.0/.

\section{References}

Alabrudzińska A, Słomczyński R, Kaliński A, Wawrzyniak J, Zieliński P, Bańbura J (2003) Effects of nests characteristics on breeding success of Great Tit Parus major. Acta Ornithol 38:151-154

Allander K (1998) The effects of an ectoparasite on reproductive success in the Great Tit: a 3-year experimental study. Can J Zool $76: 19-25$

Alvarez E, Belda EJ, Vardejo J, Barba E (2013) Variation in Great Tit nest mass composition and its breeding consequences: a comparative study in four Mediterranean habitats. Avi Biol Res 6:39-46

Bańbura J, Bańbura M, Glądalski M, Kaliński A, Markowski M, Michalski M, Nadolski J, Skwarska J, Zieliński P (2011) Body condition parameters of nestling Great Tits Parus major in relation to experimental food supplementation. Acta Ornithol 46:207-212

Bańbura J, Blondel J, Sauvages A, Galan M-J, Lambrechts MM (2001) Sex differences in parental care in a Corsican Blue Tit Parus caeruleus population. Ardea 89:517-526

Becker WA (1984) Manual of quantitative genetics. Academic Enterprises, Pullman

Benskin CMWH, Wilson K, Jones K, Hartley IR (2009) Bacterial pathogens in wild birds: a review of the frequency and effects of infection. Biol Rev 84:349-373

Berger S, Disko R, Gwinner H (2003) Bacteria in starling nests. J Ornithol 144:317-322

Bullen JJ (1981) The significance of iron in infection. Rev Infect Dis 6:1127-1138

Burtt EHJ, Ichida JM (1999) Occurrence of feather degrading bacilli in the plumage of birds. Auk 116:364-372

Carina-Audisio M, Oliver G, Apella MC (2000) Protective effect of Enterococcus faecium J96, a potential probiotic strain, on chicks infected with Salmonella pullorum. J Food Protect 63:1333-1337

Collias NE, Collias EC (1984) Nest building and bird behaviour. Princeton University Press, Princeton

Cook MI, Beissinger SR, Toranzos GA, Rodriguez RA, Arendt WJ (2005) Incubation reduces microbial growth on eggshells and the opportunity for trans-shell infection. Ecol Lett 8:532-537

Crawley MJ (2002) Statistical computing: an introduction to data analysis using S-plus. Wiley, Chichester

Devaynes A, Antunes A, Bedford A, Ashton P (2018) Progression in the bacterial load during the breeding season in nest boxes occupied by the Blue Tit and its potential impact on hatching or fledging success. J Ornithol 159:1009-1017

Glądalski M, Bańbura M, Kaliński A, Markowski M, Skwarska J, Wawrzyniak J, Zieliński P, Cyżewska I, Mańkowska D, Bańbura J (2016) Effects of human-related disturbance on breeding success of urban and non-urban blue tits (Cyanistes caeruleus). Urban Ecosyst 19:325-1334

Glądalski M, Kaliński A, Wawrzyniak J, Bańbura M, Markowski M, Skwarska J, Bańbura J (2018) Physiological condition of nestling great tits Parus major in response to experimental reduction in nest micro- and macro-parasites. Conserv Physiol 6:coy062. https://doi.org/10.1093/conphys/coy062

Gonzalez-Braojos S, Vela AI, Ruiz-de-Casteñeda R, Briones V, Cantarero A, Moreno J (2012) Is nestling growth affected by nest reuse and skin bacteria in Pied Flycatchers Ficedula hypoleuca? Acta Ornithol 47:119-127

Gonzalez-Braojos S, Vela AI, Ruiz-de-Casteñeda R, Briones V, Cantarero A, Moreno J (2015) Bacteria on nestling skin in relation to growth in pied flycatcher. J Ornithol 156:327-330

Goodenough AE, Stalwood B (2010) Intraspecific variation and interspecific differences in the bacterial and fungal assemblages of Blue Tit (Cyanistes caeruleus) and Great Tit (Parus major) nests. Microbial Ecol 59:221-232

Goodenough AE, Stalwood B (2012) Differences in culturable microbial communities in bird nestboxes according to orientation and influences on offspring quality in Great Tits (Parus major). Microb Ecol 63:986-995

Gosler A (1993) The Great Tit. Hamlyn, London

Gunderson AR, Forsyth MH, Swaddle JP (2009) Evidence that plumage bacteria influence feather coloration and body condition of eastern bluebirds Sialia sialis. J Avi Biol 40:440-447

Hansell M (2000) Bird nest and construction behaviour. Cambridge University Press, Cambridge

Heck RH, Thomas SL, Tabata LN (2010) Multilevel and longitudinal modeling with IBM SPSS. Routledge, New York

Heeb P, Kolliker M, Richner H (2000) Bird-ectoparasite interactions, nest humidity, and ectoparasite community structure. Ecology 81:958-968

Hill R, Smith IM, Mohammadi H, Licence ST (1997) Altered absorption and regulation of iron in chicks with acute Salmonella gallinarum infection. Res Vet Sci 22:371-375

Hubalek Z (1978) Coincidence of fungal species associated with birds. Ecology 59:438-442

Hubalek Z (2004) An annotated checklist of pathogenic microorganisms associated with migratory birds. J Wild Dis 40:639-659

IBM SPSS Statistics 22 (2013) SPSS for Windows, Release 22.0, IBM Corporation

Jacob S, Immer A, Leclaire S, Parthuisot N, Ducamp C, Espinasse G, Heeb P (2014) Uropygial gland size and composition varies according to experimentally modified microbiome in Great tits. BMC Evol Biol 14:134

Kaliński A, Bańbura M, Glądalski M, Markowski M, Skwarska J, Wawrzyniak J, Zieliński P, Cyżewska I, Bańbura J (2016) Relationship between blood haemoglobin and glucose concentrations in adult Great Tits (Parus major) and Blue Tits (Cyanistes caeruleus). Avi Biol Res 9:152-158

Kaliński A, Bańbura M, Glądalski M, Markowski M, Skwarska J, Wawrzyniak J, Zieliński P, Bańbura J (2017) Relationships between nestling hemoglobin concentration and brood performance until fledging in Great Tits Parus major and Blue Tits Cyanistes caeruleus. Acta Ornithol 52:141-148

Kaliński A, Bańbura M, Glądalski M, Markowski M, Skwarska J, Wawrzyniak J, Zieliński P, Cyżewska I, Bańbura J (2015) Longterm variation in hemoglobin concentration in nestling great tits Parus major. Comp Biochannel Physiol A 185:9-15

Kostelecka-Myrcha A, Jaroszewicz M (1993) The changes in the values of red blood indices during the nestling development of the house martin Delichon urbica. Acta Ornithol 28:39-46

La Ragione MR, Casula G, Cutting SM, Woodward JM (2001) Bacillus subtilis spores competitively exclude Escherichia coli O78:K80 in poultry. Vet Microbiol 79:133-142

Leclaire S, Perret P, Chatelain M, Gasparini J (2014) Feather bacteria affects plumage condition, iridescent color and investment in preening in pigeons. Behav Ecol 25:1192-1198 
Lee WY, Mincheol K, Jablonski PG, Choe JC, Lee S-i (2014) Effect of incubation on bacterial communities of eggshells in a temperate bird, the Eurasian Magpie (Pica pica). PLoS ONE 9(8):e103959. https://doi.org/10.1371/journal.pone.0103959

Lessells CM, Boag PT (1987) Unrepeatable repeatabilities: A common mistake. Auk 104:116-121

Mainwaring MC (2011) The use of nestboxes by roosting birds during the nonbreeding season: a review of the costs and benefits. Ardea 99:167-176

Mills TK, Lombardo MP, Thorpe PA (1999) Microbial colonization of the cloacae of nestling tree swallows. Auk 116:947-956

Minias P (2015) The use of heamoglobin concentrations to assess physiological condition in birds: a review. Conserv Physiol 3:1-15

Moreno J, Briones V, Merino S, Ballesteros C, Sanz JJ, Tomas G (2003) Beneficial effects of cloacal bacteria on growth and fledging size in nestling pied flycatchers (Ficedula hypoleuca) in Spain. Auk 120:784-790

Piersma T, Dekker M, Sinninghe Damste JS (1999) An avian equivalent of make-up? Ecol Lett 2:201-203

Pinowski J, Barkowska M, Kruszewicz AH, Kruszewicz AG (1994) The causes of the mortality of eggs and nestlings of Passer spp. J Biosci (Bangalore) 19:441-451

Pishchany G, McCoy AL, Torres VJ, Krause JC, Crowe JE Jr, Fabry ME, Skaar EP (2010) Specificity for human hemoglobin enhances Staphylococcus aureus infection. Cell Host Microb 8:544-550

Potti J, Moreno J, Yorio P, Briones V, Garcia-Borboroglu P, Villar S, Ballesteros C (2002) Bacteria divert resources from growth for magellanic penguin chicks. Ecol Lett 5:709-714
Saag P, Tilgar V, Mänd R, Kilgas P, Mägi M (2011) Plumage bacterial assemblages in a breeding wild Passerine: relationship with ecological factors and body condition. Microb Ecol 61:740-749

Singleton DR, Harper RG (1998) Bacteria in old House Wren nests. J Field Ornithol 69:71-74

Słomczyński R (2006) Wpływ pasożytniczych stawonogów na przebieg rozrodu i kondycję piskląt sikor bogatki Parus major i modrej Parus caeruleus. PhD thesis, Uniwersytet Łódzki, Łódź

Słomczyński R, Kaliński A, Wawrzyniak J, Bańbura M, Skwarska J, Zieliński P, Bańbura J (2006) Effects of experimental reduction in nest micro-parasite loads on nestling hemoglobin level in blue tits Parus caeruleus. Acta Oecol 30:223-227

Soler JJ, Martin-Vivaldi M, Peralta-Sanchez JM, Ruiz-Rodriguez M (2010) Antibiotic-producing bacteria as a possible defence of birds against pathogenic microorganisms. Open Ornithol J 3:93-100

Soler JJ, Martin-Vivaldi M, Ruiz-Rodriguez M, Valdivia E, MartinPlatero AM, Martinez-Bueno M, Peralta-Sanchez JM, Mendez M (2008) Symbiotic association between hoopoes and antibioticproducing bacteria that live in their uropygial gland. Funct Ecol 22:864-871

Vel'ky M (2006) Patterns in winter roosting and breeding of birds in nest-boxes. Tichodroma 18:89-96

Whittow GC (ed) (2000) Sturkie's Avian physiology. Academic Press, San Diego

Publisher's Note Springer Nature remains neutral with regard to jurisdictional claims in published maps and institutional affiliations. 